Arab World English Journal (AWEJ) Volume 12. Number4 December 2021 DOI: https://dx.doi.org/10.24093/awej/vol12no4.29

\title{
Investigation into Common Errors in English Writing among Non-Academic Staff at a Malaysian Public University
}

Ahmad Taufik Hidayah Abdullah

Faculty of Languages and Communication

Universiti Sultan Zainal Abidin, Malaysia

Mohd Nazri Latiff Azmi

Faculty of Languages and Communication

Universiti Sultan Zainal Abidin, Malaysia

Isyaku Hassan

Faculty of Languages and Communication

Universiti Sultan Zainal Abidin, Malaysia

\section{Engku Suhaimi Engku Atek}

Faculty of Languages and Communication

Universiti Sultan Zainal Abidin, Malaysia

Correspondence Author: esuhaimi@unisza.edu.my

\section{Zailani Jusoh}

Faculty of Languages and Communication Universiti Sultan Zainal Abidin, Malaysia

\section{Abstract}

The Malaysian government has long recognized the significance of mastering the English language among its citizenry. The government has planned, and subsequently, implemented many policies to ensure Malaysians master the English language. Although civil servants have a strong desire to master the English language to perform their duties more efficiently, poor English communication skills have become a major concern in this regard. Therefore, this research aims to investigate common errors in writing the English language among non-academic staff at Universiti Sultan Zainal Abidin (UniSZA), a public university in Malaysia. The study employed an Error Analysis approach by conducting document analysis where every respondent was required to write a paragraph in the English language in about 150-200 words on the topic "My greatest challenge as a UniSZA officer". The findings revealed that a sizeable number of non-academic staff committed different types of errors in writing the English language, including errors related to subject-verb agreement, passive voice, plurality, choice of word, omission of word, use of article, tense sequence, word ordering, gerund, addition of word/redundancy, and comparison of adjective. It was observed that lack of linguistic skills, lack of exposure, and inadequate practices in written English were the main factors contributing to the English writing errors among the non-academic staff. These findings could help the university management to develop appropriate programs that can assist the non-academic staff to develop English writing competence. However, this study is limited to English writing errors. Further research may focus on other language skills such as speaking and listening.

Keywords: English language, common error, Malaysian public university, non-academic staff, writing, UniSZA Cite as: Abdullah, A. T. H., Azmi, M. N. L. , Hassan, I., Atek, E. S.E., \& Jusoh, Z.(2021). Investigation into Common Errors in English Writing among Non-Academic Staff at a Malaysian Public University. Arab World English Journal, 12 (4) 446-461. DOI: https://dx.doi.org/10.24093/awej/vol12no4.29 


\section{Introduction}

Looking at its widespread use globally, such as in economics, politics, culture, and sports, the English language has a unique function and lineage among the world's major languages. Without this international language, our world today appears unable to connect and communicate. In a nutshell, this worldwide language has become a lingua franca for the entire world's population. During the last few years, the concept of English as a Lingua Franca (ELF) has sparked a lot of discussions. What emerges from most of the debate, though, is that there appears to be a great degree of ambiguity about what ELF is and how it relates to the much more firmly established field of world Englishes (Jenkins, 2009).

English has become an international medium of communication. The mastery of English is deemed as having an edge and can bring a lot of advantages to its speakers. Malaysia has long considered the importance of mastering the English language. The government has planned, and subsequently, implemented many policies to ensure Malaysians master the English language starting from primary schools to tertiary levels of education (Abdullah, 2013). Additionally, the government sectors recognize the value of mastering the English language. Those who work as civil employees in government agencies have a strong desire to master the English language to perform their duties and tasks more efficiently. Universities are one of the government sectors where employees must be fluent in this worldwide language. However, "poor English communication skills have become a major concern in the country" (Hassan, Abdul Rahaman, \& Azmi, 2021, p. 378).

As a result, universities that welcome international students must be prepared to meet their every need, both academically and in terms of their well-being throughout their time at the university. Some of the most sought-after criteria that foreign students look out for before deciding to pursue their studies abroad are state-of-the-art facilities, attractive tuition fees, prospective academic programs, future careers after graduation, distinguished professors or lecturers, and a conducive learning environment. Aside from the academic staff who serves as the university's backbone, non-academic personnel plays an essential role in assuring students' well-being and the smooth functioning of their studies in Malaysia.

Officers at the university level are often chosen among staff with bachelor's degrees. These officers are responsible for overseeing the smooth operation of the office, and they are occasionally assigned to attend meetings with other institutions or entities that require them to communicate in English. In this situation, staff with a strong command of the English language will have an advantage over those who are handicapped by the language due to their lack of command of the language.

The problem was initially observed by one of the researchers when teaching an English Intensive Course for non-academic staff at Universiti Sultan Zainal Abidin (UniSZA), Malaysia. The researchers, cum an instructor at the time, concluded that the majority of the non-academic officers still committed many grammatical errors in using the English language in their written work. The same opinion was also shared by the other three teachers who taught English in the course. This prompted the researchers to initiate this research to help improve the level of written English among non-academic officers. In this study, the researchers intend to identify the 
Arab World English Journal (AWEJ) Volume 12. Number 4. December 2021

most common errors committed by non-academic officers at UniSZA in writing the English language.

\section{Literature Review}

The Role of English Language to Administrative and Support Staff in Malaysian Public Universities

Non-academic staff members are professional personnel who make a substantial contribution to a university's performance. They bring a valuable set of professional talents to the university, as well as a wealth of institutional knowledge, vital resources, and a willingness to collaborate with professors and administration in accomplishing the university's vision and goal. The involvement of non-academic employees has a significant influence on the university's student experience and studies.

While faculties assist students in academic matters and research, non-academic employees have an equal role in ensuring students' success by providing vital support and operational services. Non-academic staff personnel assist students with admissions and registration, orientation to the institution, residential life programming, and a variety of nonacademic learning activities, as well as helping them prepare for their next professional stage. In addition, staff employees in academic departments or student service units are frequently the first points of contact for a large number of students who require assistance in some way. In short, non-academic staff at each university play a critical role in guaranteeing the institution's seamless administration. As non-academic staff is also expected to meet the need of international students, investigating their English proficiency may serve to offer the general picture envisioned.

\section{Errors and Mistakes in Learning English as Second Language}

According to behaviorist learning theory, past habits influence how new habits are learned (Ellis, 1998). The grammar imprinted into the mind as the first language will obstruct the easy acquisition of the second language when studying a second language. This interference occurs as a result of proactive inhibition, which occurs when existing learning prevents the acquisition of new behaviors. When students transfers the realization device from their first language to the second, an error is likely to occur in the second language because the learners will transfer the realization device from their first language to the second language.

During the process of learning a foreign language, mistakes and errors "are unavoidable constitutes" ( $\mathrm{Li}, 2021$, p. 238). Although the terms "mistakes" and "errors" appear to be interchangeable, they are not the same. A mistake is a type of performance fault in which the learner wrongly uses the language. On the other hand, an error is a structure that deviates from the standard language reflecting the interlanguage ability of the learner (Kirkgoz, 2010).

Lightbown and Spada (2006) asserted that errors in language acquisition and understanding of grammar had become essential factors that signal the growth of the second language (L2) learners' interlanguage system. This view was also quoted by Muftah and Galea (2013). Errors are defined as aspects of learners' utterances that differ in some manner from those 
of native speakers, and learners of a target language are unaware of their errors, and hence unable to fix them (Corder, 1981). Error Analysis is the process of encountering, computing, and analyzing these errors. Error Analysis, according to Richards (1984), as cited in Tomlinson (2011), is the study and analysis of errors produced by learners of a second or foreign language.

Even in the first language, writing is a difficult task. Writing in a foreign language is undoubtedly more difficult. As a result, many scholars have attempted to identify the most prevalent writing errors made by English as a Foreign Language (EFL) students. Teachers will be able to better recognize students' difficulties in learning the language if they better understand the errors they make and where they come from in the EFL writing process. It will also assist in implementing appropriate teaching practices to help EFL students learn more effectively (Heydari \& Bagheri, 2012).

The notion of mistakes and errors are differentiated, following their processes and implications towards language teaching and learning. Some linguists have come up with various definitions as scholars have different ways of looking at and differentiating the two concepts.

Edge (1994) makes an analogy by giving examples of someone who writes sentences that contain some deviant sentences. In the case that the person could correct the deviant sentences himself after the mistakes were pointed, it is called a "mistake". It is believed that if the person pays attention to the details, he/she could easily put the deviant sentences right. In this case, if the matter is seen from the angle of a teacher, regardless of what causes the mistakes, if students were able to correct the deviant sentences by themselves, this is called a "mistake". On the other hand, there is another category for mistakes that individual students could not correct even if they were pointed out. In this case, if students cannot self-correct a mistake in their English, even when the mistakes are pointed out, then the students can be assured of having committed an "error".

Bartram and Walton (2001) distinguished between "mistake" and "error". According to them, mistakes occur due to learners' inability to put what they have learned into practice. On the other hand, Errors happen when learners try out something completely new and get it wrong. Ellis (1998) also distinguished between the two terms. According to him, Errors refer to gaps in learners' knowledge, and they happen due to learners' lack of knowledge of correct grammatical forms. On the other hand, Mistakes represent infrequent gaps in performance, and at times, they occur because of learners' inability to accomplish what they already knew.

From the three definitions and differences given above, it can be summarized that mistakes happen due to carelessness. They know the right forms, but due to some reasons such as memory lapses, physical states such as tiredness, psychological conditions such as strong emotions, or being in a hurry, they commit mistakes. Learners can correct mistakes once the mistakes are spotted. On the other hand, Errors happen due to learners' lack of knowledge. They seem to consistently make the same mistakes. Learners are unable to correct errors even if the errors are spotted. 


\section{Theoretical Approach: Error Analysis}

This study is guided by the Error Analysis approach. The tradition of error analysis started a long time ago. In the early 1970s, Error Analysis entailed merely generalized assortments of common errors and their language categorization. At that time, the objectives of traditional Error Analysis were primarily educational, where information obtained from errors might be utilized to structure learning tools or to conduct instructions (Ellis, 1998). The nonexistence of theoretical background to conceptualize the contribution of errors to language acquisition resulted in the absence of any serious effort to explain or theorize errors from psychological perspectives. However, Corder (1974) published several articles that invigorated the importance of Error Analysis. Additionally, Corder employed a process of Error Analysis as follows.

a) First, a corpus of language is carefully chosen. This stage entails determining the sample size, the sampling medium as well as the sample's homogeneity which includes the age groups and first language of learners.

b) Then, errors in the corpus language are identified. At this stage, lapses (such as deviant sentences that occurred due to processing difficulties other than lack of proficiency) are distinguished from errors. For instance, some sentences could be "overtly idiosyncratic" (illconstructed in terms of rules of the target language) or "covertly idiosyncratic" (superficially well-constructed but ungrammatical in terms of their context of use).

c) Next, errors are categorized. This stage consists of assigning each error with particular grammatical descriptions.

d) Afterward, errors are explained in detail, where attempts are made to ascertain the psycholinguistic root causes of the errors made.

e) Finally, errors are assessed and evaluated. At this point, the significance or seriousness of each error is assessed to make principled pedagogical decisions. The error assessments are needed only when the intention of the analysis is pedagogical.

In essence, the most substantial influence of Error Analysis in Second Language Acquisition (SLA) lies in its advancement of the concept of errors to conceptualize the language pedagogic process (Ellis, 1998). Owing to the conceptualization of Error Analysis concerning interlanguage practices, errors are no longer viewed as "undesirable or unwanted forms", but as a signal of learners' active participation in contributing to SLA.

Errors usually happen due to learners' lack of knowledge, and they usually occur continuously. The errors tend to occur in many aspects of grammar (Mashoor \& Abdullah, 2020). Error Analysis tries to shed light on this phenomenon to transform the phenomenon of errors from something that is feared or avoided to something significant pedagogically. Thus, this effort could help both teachers and students in the process of teaching and learning, whereby the students' errors are identified, classified, explained, and finally evaluated. Upon completion of this process, it is hoped that errors committed by the students will be a catalyst for the teachers to rectify the weaknesses of their students and employ certain remedial efforts to help the students master the language more effectively.

\section{Past Studies}




\section{Past Study on the Use of English Language among Non-Academic Staff}

There was a study by Mahadi, Ambigapahty, and Kaur (2019) on the role of the English language in two public universities in Malaysia involving administrative and support staff. The study looked at how the non-academic staff is equipped linguistically to meet the challenges of globalization. Altogether, 326 respondents from two public universities were involved in the study. The first finding revealed that only an insignificant number of the respondents mentioned that they regularly attended to letters and inquiries in English. Moreover, more than a third of the respondents never or rarely address such inquiries. However, these statistics have not specified whether the respondents were initially assigned with such responsibilities. Perhaps, they never obtained written inquiries, particularly in English, because their professional tasks do not primarily involve handling inquiries.

The research outcome also indicated that about $20 \%$ of the respondents mentioned that they always or frequently communicate in English at the workplace. Also, most of them responded negatively; they seldom or never used English to communicate at the workplace. The findings also showed that only $12 \%$ of the respondents mentioned that notifications sent to them were frequently produced in English. Additionally, about 20\% of them mentioned that they frequently or always received information in English from the heads of their departments. The rest of the respondents stated that they were seldom or never given instructions in English.

\section{Past Studies on Errors in Writing the English language}

Research shows that "writing proficiency is considered more complex and challenging than other language skills" (Hassan et al., 2021, p. 378). As such, some studies focused specifically on writing issues among English language learners, including English writing errors. For instance, Kirkgoz (2010) analyzed written errors of Turkish adult learners of English. The study identified four types of errors committed by the learners, namely: Grammatical interference of pluralization (Examples: There are two telephones on the table, We have a big garden and three dogs), Verbtense (Examples: My family is living in Malaysia, they are loving their children), Prepositional interference (Examples: I am going home, He is watching to TV), and Lexical interference (Examples: Bilge is a large garden (should be "has"), He is some fat (no "some")

Another study was carried out by Muftah and Galea (2013) on error analysis of present simple tense in the interlanguage of adult Arab English language learners. The study revealed that the respondents committed two most common errors, which were: omission of the third person singular agreement morpheme $\underline{s}$ (Examples: He complained that I am too slow, Tam speak English very well) and the suffixation of -ing (Example: Every time Tam says a new word, Liam trying to repeat it).

Additionally, Özkayran and Yilmaz (2020) examined English writing errors among university students in Turkey. According to the study, a total of 381 errors were committed by the students, including misformation errors, omission errors, and misordering errors. The findings revealed that misformation errors were common among the students. The study recommends that English language teachers "should focus more on prepositions, verb "to be", spelling, articles, singular/plural forms of nouns, word formation, tenses, word choice and 
subject-verb agreement, which were the most problematic areas of language" (p. 48). Also, Li (2021) found that misuse of tenses and articles are the most common errors committed by English learners. These errors, according to the study, are primarily due to some factors such as "thought patterns and lack of knowledge" (p. 240).

Previous studies on English writing errors focused on students' errors at different educational levels, especially higher institutions and universities (Muftah \& Galea, 2013; Özkayran \& Yilmaz, 2020). To the best of our knowledge, none of the previous studies focused on English writing errors among non-academic staff, particularly in public universities. Thus, we investigate English writing errors committed by non-academic staff at UniSZA, a public university on the East Coast of Peninsular Malaysia.

\section{Methodology}

This research employed a qualitative approach in which Error Analysis was conducted, where every respondent was required to write a paragraph in the English language in about 150-200 words on the topic My greatest challenge as a UniSZA officer. The total number of nonacademic staff from grades 41-54 during the data collection was 197. By referring to the Krejcie and Morgan table (1970), with a population of 197 staff, the researchers selected a sample of 132 non-academic officers for this research, comprising those holding grades 41-54 and working either in faculties, institutes, and other departments at the selected university.

To answer the research question: What are common errors in writing English among nonacademic officers from grades 41 to 54 at Universiti Sultan Zainal Abidin? The researchers employed Error Analysis procedures and analyzed the respondents' written works from the English linguistic point of view, especially from the structural and grammatical aspects.

\section{Findings and Discussion \\ Demographic Background of the Respondents}

Altogether, 150 questionnaires were administered to administrative staff at Universiti Sultan Zainal Abidin (UniSZA), a public university on the east coast of the country, where the last part of the questionnaire asked the respondents to write a paragraph to analyze of their writing work. Out of 150 copies of distributed questionnaires, only 139 were duly returned. There was nearly equal number of female and male respondents with age groups ranging from 24-59 (an average age of 30.1 years). With regard to the respondents' years of service at UniSZA, most of them $(44 \%)$ have served the university for 6-10 years. Figure 1 shows the respondents' demographic information. 


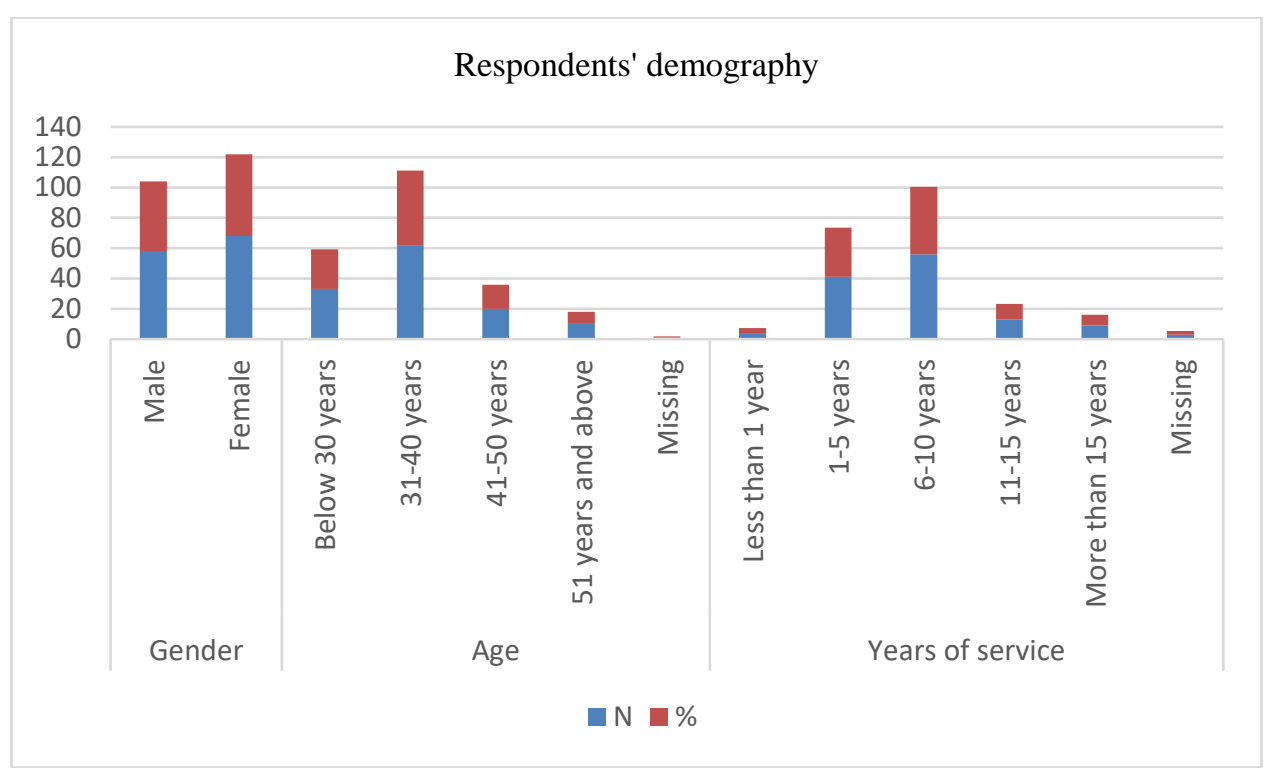

Figure 1. Demographic information of the respondents

\section{Common Errors in Writing the English Language among Non-Academic Staff from Grade 41 to 54 at Universiti Sultan Zainal Abidin}

To answer this research question, the respondents were asked to write an essay on a topic related to their work titled 'My greatest challenge as a UniSZA officer'. This was to ensure that they would be able to express themselves freely in writing an essay topic they were familiar with. After analyzing their essays, it was found that the respondents produced numerous types of errors on the following items:

\section{Errors in the usage of verbs}

Our findings show that the respondents do not adhere to the rules of subject-verb agreement and Be+Verb Stem for Verb Stem. Examples of the errors and their corrections are listed as follows. Table 1. Errors in the usage of verbs

\begin{tabular}{|l|l|l|}
\hline \multicolumn{2}{|c|}{ 1. $\quad$ Subject-Verb agreement errors } \\
\hline SN & Errors & Corrections \\
\hline 1 & $\begin{array}{l}\text { English become something that I feel not } \\
\text { comfortable }\end{array}$ & $\begin{array}{l}\text { English becomes something that I feel not } \\
\text { comfortable with }\end{array}$ \\
\hline 2 & $\begin{array}{l}\text { Usually, this task need to be completed in } \\
\text { a short period of time }\end{array}$ & $\begin{array}{l}\text { Usually, this task needs to be completed in a short } \\
\text { period of time }\end{array}$ \\
\hline 3 & $\begin{array}{l}\text { To be a good science officer both } \\
\text { knowledge are needed. }\end{array}$ & $\begin{array}{l}\text { To be a good science officer both knowledge is } \\
\text { needed. }\end{array}$ \\
\hline 4 & That payment are paid early. & That payment is paid early. \\
\hline SN 2. & Be+Verb Stem for Verb Stem & Corrections \\
\hline 1 & $\begin{array}{l}\text { Same situation was happened when I was } \\
\text { at faculty. }\end{array}$ & Same situation happened when I was at faculty. \\
\hline 2 & I was started my carrier in Kusza in 1999. & I started my carrier in Kusza in 1999. \\
\hline 3 & I'm start working at UniSZA in 2005. & I started working at UniSZA in 2005. \\
\hline
\end{tabular}

ISSN: 2229-9327 
\begin{tabular}{|l|l|l|l}
\hline 4 & Previously I'm worked in private sector & Previously I worked in private sector company.
\end{tabular} company.

There are two most common errors related to the usage of verbs in the English language. Firstly it deals with subject-verb agreement errors, and secondly, it deals with the use of Be+Verb Stem for Verb Stem. These types of errors are very common among the respondents. The subject-verb agreement rule in English grammar stipulates that a singular subject must always be followed by a singular verb. A singular verb is usually indicated by the use $-s$ or $-e s$ after the base verb. Likewise, a plural subject takes a plural verb. A plural subject in English is indicated by the use of the base verb without the addition of derivative $-s$ or $-e s$. On the other hand, errors related to $B e+$ Verb Stem for Verb Stem are also common among the respondents.

\section{Subject-Verb agreement errors}

As shown in the above examples, the respondents did not add $-s$ to make the verb singular to conform with the singular noun subject. The respondents did not add $-s$ or -es to the verb. Most of the errors are found when dealing with singular subjects. One possible explanation is that the respondents were unaware of the grammatical rule that if the subject is singular, the verb must be singular, thus omitting $-s$ or -es. Another possible explanation is that the respondents might have been confused with the different usage of $-s$ or $-e s$ in nouns and verbs. In English, the plural subject is created by adding $-s$ or - es to the noun but for verbs, only singular verbs add $-s$ or $-e s$ to the base verb. A third possible explanation is that the respondents could not comprehend the concept of subject-verb agreement as it is non-existent in the Malay language.

In all the above examples, the respondents did not apply the proper subject-verb agreement formation. All the subjects in those sentences are singular but the plural verb is used instead. This is an indication the respondents have no grasp of the concept of the English language subject-verb agreement.

\section{Be+Verb Stem for Verb Stem}

This is another common type of error made by the respondents. In this type of error, the respondents failed to apply the correct form of the past tense in their sentences.

All the above errors suggest that the respondents did not adhere to the simple use of either present or past tense. In all of those sentences, the respondents used the be + verb formation, thereby adding the auxiliary verb was or am preceding the verb when it was not needed. All the above sentences only required a simple present or simple past tense formation. This suggests that their understanding of the simple tense concept is flawed as they were unable to produce the correct form.

\section{Errors in choosing proper words in the English language}

The research findings show that the respondents have committed to making some errors concerning the use of part of speech, plurality, and comparison of adjectives. Examples of the errors and their corrections are listed as follows.

Table 2 : Errors in choosing proper words in the English language

\begin{tabular}{lll}
\hline \multicolumn{1}{l|}{. Errors in using proper part of speech } & \\
\hline \hline Arab World English Journal & www.awej.org & 454 \\
ISSN: $2229-9327$ &
\end{tabular}


Arab World English Journal (AWEJ) Volume 12. Number 4. December 2021

\begin{tabular}{|c|c|c|}
\hline SN & Errors & Corrections \\
\hline 1 & $\begin{array}{l}\text { I have to check their problem and } \\
\text { understand their cultural. }\end{array}$ & $\begin{array}{l}\text { I have to check their problem and understand their } \\
\text { culture. }\end{array}$ \\
\hline 2 & $\begin{array}{l}\text { Right now, we feel a little bit comfort } \\
\text { compared to } 2 \text { previous years. }\end{array}$ & $\begin{array}{l}\text { Right now, we feel a little bit comfortable compared } \\
\text { to } 2 \text { previous years. }\end{array}$ \\
\hline 3 & $\begin{array}{l}\text { I found out majority of UniSZA staff are } \\
\text { more dependence to IT staff. }\end{array}$ & $\begin{array}{l}\text { I found out the majority of UniSZA staff are more } \\
\text { dependent on IT staff. }\end{array}$ \\
\hline \multicolumn{3}{|c|}{ 2. Errors in using plurality } \\
\hline $\mathrm{SN}$ & Errors & Corrections \\
\hline 1 & $\begin{array}{l}\text { One of the challenge as a librarian is how } \\
\text { to deal with the foreign students. }\end{array}$ & $\begin{array}{l}\text { One of the challenges as a librarian is how to deal } \\
\text { with the foreign students. }\end{array}$ \\
\hline 2 & $\begin{array}{l}\text { There are so many task that we have to } \\
\text { complete at the same time. }\end{array}$ & $\begin{array}{l}\text { There are so many tasks that we have to complete at } \\
\text { the same time. }\end{array}$ \\
\hline 3 & $\begin{array}{l}\text { Since UniSZA has international students } \\
\text { and } \underline{\text { staffs, }} \text {, so we have to be good } \\
\text { in English }\end{array}$ & $\begin{array}{l}\text { Since UniSZA has international students and staff, so } \\
\text { we have to be good at English conversion. }\end{array}$ \\
\hline \multicolumn{3}{|c|}{ Errors in making comparison of adjectives } \\
\hline $\mathrm{SN}$ & Errors & Corrections \\
\hline 1 & I hope my English is more better. & I hope my English is better \\
\hline 2 & $\begin{array}{l}\text { They are a lot of senior staff which work } \\
\text { more longer than me. }\end{array}$ & $\begin{array}{l}\text { They are a lot of senior staff who work longer than } \\
\text { me. }\end{array}$ \\
\hline
\end{tabular}

Errors in using proper part of speech

This type of error indicates the inability of the respondents to produce the right choice of words in their writing. As shown by the examples above, some of our respondents did not choose the right vocabulary in their essay writing. These errors can be attributed to them not being able to distinguish a noun from an adjective, hence the mix-up. For example, in sentence 1, the noun culture should have been used instead of the adjective cultural. In sentence 2, it is the opposite, the noun comfort was chosen instead of the correct adjective form of comfortable. Likewise, sentence 3 exhibits their application of the wrong words in the sentence owing to their inability to differentiate the word forms.

\section{Errors in using the plurality}

This is one of the most common errors produced by the respondents in their writing. Our findings above show that the respondents retained the singular form of the noun for plurality as indicated in examples 1 and 2. In example 3, the countable noun staff is used to indicate both singular and plural. It is possible that in this context, some of the respondents assumed all countable nouns are formed by adding $-s$ or - es. In many instances, this is true but some English nouns do make exceptions to this rule.

\section{Errors in making the comparison of adjectives}

This research also found that our respondents produced errors in the use of comparison of adjectives. A comparison of an adjective is an adjective used to compare two individuals or objects. In English, a comparison is shown mainly by adding -er to the adjective. In less common formation, the word more is used to indicate comparison. In both sentences shown above, the respondents committed errors in their use of comparison of adjectives The respondents used both 
-er and more when making the comparison. This is unacceptable in English as the norm is to add $-e r$ to the adjectives.

\section{Errors in using passive voice and article}

Our findings also show that the respondents do not adhere to the rules of passive voice and in the use of the proper article as shown in the examples below.

Table 3: Errors in using passive voice and article

\begin{tabular}{|c|c|c|}
\hline \multicolumn{3}{|c|}{ 1. Errors in using passive voice } \\
\hline SN & Errors & Corrections \\
\hline 1 & $\begin{array}{l}\text { PTD and PTN can be appoint as a head of } \\
\text { department or division. }\end{array}$ & $\begin{array}{l}\text { PTD and PTN can be appointed as a head of } \\
\text { department or division. }\end{array}$ \\
\hline 2 & $\begin{array}{l}\text { UniSZA is one of the public university } \\
\text { which is control by the ministry of higher } \\
\text { education (MOHE). }\end{array}$ & $\begin{array}{l}\text { UniSZA is one of the public universities which is } \\
\frac{\text { controlled by the ministry of higher education }}{\text { (MOHE). }}\end{array}$ \\
\hline 3 & $\begin{array}{l}\text { Assistant registrar normally not given the } \\
\text { opportunity to give their views or } \\
\text { opinions. }\end{array}$ & $\begin{array}{l}\text { Assistant registrar normally is not given the } \\
\text { opportunity to give their views or opinions. }\end{array}$ \\
\hline \multicolumn{3}{|c|}{ 2. Errors in using article } \\
\hline SN & Errors & Corrections \\
\hline 1 & $\begin{array}{l}\text { During my service as a academic staff at } \\
\text { faculty of Design and Technology, I felt } \\
\text { very unconfident to give a speech in a } \\
\text { public. }\end{array}$ & $\begin{array}{l}\text { During my service as an academic staff at the faculty } \\
\text { of Design and Technology, I felt very unconfident to } \\
\text { give a speech in a public. }\end{array}$ \\
\hline 2 & As a officer, the consideration is needed. & As an officer, consideration is needed. \\
\hline 3 & $\begin{array}{l}\text { Instructions given to me are } \\
\text { opposite. }\end{array}$ & Instructions given to me are the opposite. \\
\hline
\end{tabular}

\section{Errors in using passive voice}

This is another type of error commonly found in the respondents' writing. The respondents were found to have formed the passive voice incorrectly. Examples 1 and 2 show that the respondents did not apply the correct formation of $b e+$ past participle of the verb to construct a grammatically correct passive sentence. In the two sentences, the verb following be was not changed to the past participle form. In example 3, the application of the passive voice is flawed because the $b e$ verb preceding the past participle form of the verb is omitted.

\section{Errors in using the article}

In this type of error, there is either an omission of an article in the sentence or an incorrect article is chosen. This refers to the use of $a$, an, the, or none at all. Example 1 shows the omission of the article the in the sentence. On the other hand, example 2 shows the incorrect use of an article where the article $a$ is used instead of $a$. Example no. 3 also shows the omission of the article the from the sentence thus making the sentence grammatically incorrect.

\section{Other common errors}

There are some other common errors committed by the respondents in the research in relation to the omission of verb to be, omission of words, tense sequence, word ordering, and the use of gerund. Although these errors were not found excessive, they still need to be addressed to ensure 
Arab World English Journal (AWEJ) Volume 12. Number 4. December 2021

Investigation into Common Errors in English Writing

Abdullah, Azmi, Hassan, Atek \& Jusoh

that their writing English language will be better in the future to meet grammatically correct English grammar. Some of the errors concerning these errors are listed below.

Table 4. Other common errors

\begin{tabular}{|c|c|c|}
\hline \multicolumn{3}{|c|}{ 1. Omission of verb to be } \\
\hline SN & Errors & Corrections \\
\hline 1 & $\begin{array}{l}\text { Culture of work at UniSZA also challenging } \\
\text { to me. }\end{array}$ & $\begin{array}{l}\text { The culture of work at UniSZA is also challenging to } \\
\text { me. }\end{array}$ \\
\hline 2 & $\begin{array}{l}\text { It difficult to contact other PTJ } \\
\text { representative after office hour. }\end{array}$ & $\begin{array}{l}\text { It is difficult to contact other PTJ representatives } \\
\text { after office hour. }\end{array}$ \\
\hline 3 & I__ very happy and like the situation. & I am very happy and like the situation. \\
\hline \multicolumn{3}{|c|}{ 2. Omission of words } \\
\hline SN & Errors & Corrections \\
\hline 1 & I am afraid _ speak in front of people. & I am afraid to speak in front of people. \\
\hline 2 & $\begin{array}{l}\text { Besides, I also need _ prepare myself to } \\
\text { serve the faculty how to prepare } \\
\text { documentation. }\end{array}$ & $\begin{array}{l}\text { Besides, I also need to prepare myself to serve the } \\
\text { faculty how to prepare documentation. }\end{array}$ \\
\hline 3 & The development ___ the university & The development of the university \\
\hline 4 & The position $\quad$ head of department ... & The position as head of the department ... \\
\hline \multicolumn{3}{|c|}{ 3. Tense sequence } \\
\hline SN & Errors & Corrections \\
\hline 1 & $\begin{array}{l}\text { You also need to cover and supervised your } \\
\text { support staff. }\end{array}$ & $\begin{array}{l}\text { You also need to cover and supervise your support } \\
\text { staff. }\end{array}$ \\
\hline 2 & $\begin{array}{l}\text { I can understand people speaking English } \\
\text { but I was nervous to talk especially in the } \\
\text { group. }\end{array}$ & $\begin{array}{l}\text { I can understand people speaking English but I am } \\
\text { nervous to talk especially in the 'group. }\end{array}$ \\
\hline \multicolumn{3}{|c|}{ 4. Word ordering } \\
\hline SN & Errors & Corrections \\
\hline 1 & $\begin{array}{l}\text { The most challenge that you need to take is } \\
\text { how can you balance the needs from } \\
\text { academicians and support's staff. }\end{array}$ & $\begin{array}{l}\text { The most challenge that you need to take is how you } \\
\text { can balance the needs of academicians and support } \\
\text { staff. }\end{array}$ \\
\hline 2 & $\begin{array}{l}\text { If we are to achieve all citizens equally } \\
\text { UniSZA uses language English always. }\end{array}$ & $\begin{array}{l}\text { If we are to achieve all citizens equally UniSZA uses } \\
\text { the English language always. }\end{array}$ \\
\hline \multicolumn{3}{|c|}{ 5. The use of gerund } \\
\hline SN & Errors & Corrections \\
\hline 1 & $\begin{array}{l}\text { I am very nervous because it is a first time I } \\
\text { have to be a chairman in speak English. }\end{array}$ & $\begin{array}{l}\text { I am very nervous because it is the first time I have to } \\
\text { be a chairman in speaking English. }\end{array}$ \\
\hline 2 & $\begin{array}{l}\text { Some people did not understand and put the } \\
\text { blame on me for not completed the task on } \\
\text { time. }\end{array}$ & $\begin{array}{l}\text { Some people did not understand and put the blame on } \\
\text { me for not completing the task on time. }\end{array}$ \\
\hline 3 & $\begin{array}{l}\text { He had a vision of privatize UniSZA's } \\
\text { clinic. }\end{array}$ & He had a vision of privatizing UniSZA's clinic. \\
\hline
\end{tabular}

\section{Omission of verb to be}

Our finding shows that some respondents are prone to omitting the be verb to be when forming sentences. Be verbs consist of am, is, are, was, were. They are either used independently as nonaction verbs in sentences or as auxiliary verbs in tenses. From our analysis, sentence 1 is missing 
the auxiliary verb is. Sentences 2 and 3 are missing the non-action verb of is and am respectively. In English, the use of be verb is fundamental in making the sentences grammatical. In contrast, in Malay, there is no equivalent form for non-action verbs. The use of the non-action verb is non-existent in Malay. Malay also does not make use of the be verb as auxiliaries in tenses.

\section{Omission of words}

This type of error refers to the sentence missing a word which renders the sentence ungrammatical. As shown above, the sentences are grammatically incorrect because they are missing a word. The omitted word in the above examples is either the to infinitive or a preposition. In sentences 1 and 2, the to infinitive is missing. In sentences 4 and 5, the preposition is missing in each of those sentences.

\section{Tense sequence}

The findings also found that some respondents used the wrong tense sequence. This is a mixing of tenses where the past tense is mixed with the present tense when only a single tense form is appropriate. In both examples 1 and 2 above, the respondents used the past tense form instead of the present tense. This indicates the inability of the respondents to apply the correct tense form in their sentences. This could be attributed to their unfamiliarity with the present time or past time concept.

\section{Word ordering}

This type of error suggests that the respondents are unable to understand word order in English sentence structure. The above examples show that the word order is incorrect. In sentence 1, the respondent probably thought that it is a question, therefore wrote ... how can you .... In sentence 2, the English word order in the noun phrase is not adhered to. In the English language, the adjective precedes the noun in the noun phrase. However, the respondent did not conform to the English word order. Most likely the word order in his or her noun phrase formation was partly influenced by the Malay language which stipulates that a noun always precedes an adjective.

\section{The use of gerund}

Some respondents are also prone to making errors in the use of gerunds. In English, gerund refers to the use of the present participle form of the verb (verb+ing) after a preposition. In the three examples above, the respondents disregarded the use of gerund following the use of prepositions in (sentence 1), for (sentence 2), and of (sentence 3). This signifies the respondents' unfamiliarity with the rules of gerund use.

The findings reported in this study revealed that non-academic staff at the selected university committed different types of errors. Nevertheless, most of these errors are basic and preventable. This outcome implies that either the respondents do not care much about English grammar and rules or they are of the view that English is neither important nor necessary for survival in their daily work.

Moreover, some of the errors identified in this study, specifically omission errors, plurality errors, and verb-tense errors, are very similar to those pointed out in previous studies (Kirkgoz, 
2010; Muftah \& Galea, 2013). Also, English language teachers were advised to focus on these types of writing errors to help learners develop competency in writing the English language (Özkayran \&Yilmaz, 2020).

\section{Conclusion}

This study explored the common errors made by non-academic staff of a public university in Malaysia. From the findings, two major conclusions are drawn. First, most of the non-academic officers, from Grade 41-54, do not command a high standard of English, judging from the errors they produced in their essay writing. This issue does not augur well for the university. As officers holding important and respectable positions, coupled with degree qualifications, they are expected to command better English. Second, the officers have not fully grasped the structures and grammatical rules of the English language, but most of the errors they committed are basic and preventable. Some types of errors are very common and keep recurring in their writing.

Therefore, this study offers some recommendations to help reduce errors in writing the English language. For example, writing courses need to be conducted for these university officers. This effort will help the officers to develop English writing proficiency and enable them to produce quality writing. The writing courses should incorporate English rules and grammar. Additionally, different methods of writing instructions could be developed. Examples of such methods include Peer correction, Underlined and Coded mistakes, Search and Correct technique, Underlining mistakes, as well as Self-Correction without indicating mistakes. Nevertheless, instructors may develop their own realistic instructional tools. This study is limited to English writing errors, and thus, further research may focus on other language skills such as speaking and listening.

\section{About the authors}

Dr. Ahmad Taufik Hidayah Abdullah is a Senior Lecturer at the Faculty of Languages and Communication, Universiti Sultan Zainal Abidin (UniSZA), Malaysia. His areas of research interest include public speaking, English linguistics, error analysis, and language learning. https://orcid.org/0000-0001-9898-0980

Dr. Mohd Nazri Latiff Azmi is an Associate Professor of English at the Faculty of Languages and Communication, Universiti Sultan Zainal Abidin (UniSZA), Malaysia. His areas of research interest include comaprative literature, applied linguistics, and language studies.https://orcid.org/0000-0002-4712-5332

Dr. Isyaku Hassan is a Postdoctoral Researcher at the Faculty of Languages and Communication, Universiti Sultan Zainal Abidin (UniSZA), Malaysia. His areas of research interest include media linguistics, interactive media, and lanaguage studies.https://orcid.org/0000-0002-8260-2894

Engku Suhaimi Engku Atek is a Senior Lecturer at the Faculty of Languages and Communication, Universiti Sultan Zainal Abidin (UniSZA), Malaysia. His areas of research 
Arab World English Journal (AWEJ) Volume 12. Number 4. December 2021

interest include Education and Instruction, and English Language Teaching. https://orcid.org/0000-0002-4889-2904

Dr. Zailani Jusoh is a Senior Lecturer at the Faculty of Languages and Communication, Universiti Sultan Zainal Abidin (UniSZA), Malaysia. She has been teaching ESL for more than two decades. Among her research interests include teacher professional development, and reading assessment. https://orcid.org/0000-0001-5923-7641

\section{References}

Abdullah, A.T. H. (2013). Error analysis on the use of the simple tense and the simple past tense in writing essays among TESL college students. International Journal of Education And Research, 1 (12), 1-12.

Bartram, M., \& Walton, R. (2001). Correction: A positive approach to language mistakes. Language Teaching Publication: London: Longman

Corder, S.P. (1981) Error analysis and interlanguage. Oxford: Oxford University Press.

Corder, S.P. (1974) The significance of learner's errors. In J.C. Richards (ed.), Error Analysis (pp. 19-27). Singapore: Longman

Edge, J. (1994). Mistakes and corrections. New York: Longman

Ellis, R. (1998). Second language acquisition. Oxford: Oxford University Press

Hassan, I., Abdul Rahaman, A. M., \& Latiff Azmi, M. N. (2021). Development of English writing skills through blended learning among ESL learners in Malaysia. Arab World English Journal (AWEJ) Special Issue on CALL, 377-389. doi: 10.24093/awej/call7.26

Heydari, P., \& Bagheri, S.M. (2012). Error analysis: Sources of L2 learner's errors. Theory and Practice in Language Studies 2 ( 8), 1583-1589. doi:10.4304/tpls.2.8.1583-1589

Jenkins, J. (2009). English as a lingua franca: Interpretations and attitudes. World Englishes, 28, ( 2), 200-207.doi: 10.1111/j.1467-971X.2009.01582.x

Kirkgoz, Y. (2010). An analysis of written errors of Turkish adult learners of English. Social and Behavioral Sciences, 2 (2), 4352-4358.doi: 10.1016/j.sbspro.2010.03.692

Krejcie, R. V., \& Morgan, D. W. (1970). Determining Sample Size for Research Activities. Educational and Psychological Measurement.

Li, Z. (2021). Error Analysis-Types and Causes of Errors in English Writing among Chinese Students. Journal of Contemporary Educational Research,5(8), 238-241. doi: 10.26689/jcer.v5i8.2487

Lightbown, P.M., \& Spada, N. (2006). How languages are learned. Oxford: Oxford University Press.

Mahadi, T.S.T, Ambigapathy, P., \& Kaur, S. (2019). Investigating the role of English language in a Malaysian public university: The case of administrative and support staff. Retrieved from: https://www.malrep.uum.edu.my/monograph

Mashoor, B. B. N., \& Abdullah, A. T. H. (2020). Error analysis of spoken English language among Jordanian secondary school students. International Journal of Education and Research, 8 (5), 75-82.

Muftah, M., \& Galea, S.R. (2013). Error analysis of present simple tense in the interlanguage of adult Arab English language learners. English Language Teaching, 6, ( 2), 146-154. doi: 
Arab World English Journal (AWEJ) Volume 12. Number 4. December 2021

10.5539/elt.v6n2p146

Özkayran, A., \& Yilmaz, E. (2020). Analysis of Higher Education Students' Errors in English Writing Tasks. Advances in Language and Literary Studies, 11(2), 4858.doi.10.7575/aiac.alls.v.11n.2-p.48

Richards, J. C. (1984). Error analysis: Perspectives on second language acquisition. London: Longman

Tomlinson, B. (Ed.) (2011). Materials development in language teaching (2nd ed.). Cambridge, UK: Cambridge University Press. 